\title{
Social Consequences of the Modern Pension Reform in Russia for the Arctic Region - Murmansk Region
}

\author{
Tatiana Skufina \\ Luzin Institute for Economic Studies - Subdivision of the \\ Federal Research Centre "Kola Science Centre of the Russian \\ Academy of Sciences" (IES KSC RAS) \\ Apatity, Russia \\ skufina@gmail.com
}

\author{
Elena Korchak \\ Luzin Institute for Economic Studies - Subdivision of the \\ Federal Research Centre "Kola Science Centre of the Russian \\ Academy of Sciences" (IES KSC RAS) \\ Apatity, Russia \\ elenakorchak@mail.ru
}

\begin{abstract}
Recently, studies on the development of conceptual provisions governing the standard of living of pensioners have been significant. Such an update is due to an increase in the retirement age of the population, increased life expectancy, as well as low level of material welfare of elderly citizens. The purpose of this study was to analyze the social challenges of modern pension reform in Russia, the subject is the standard of living of pensioners of the Murmansk region. As a methodological basis of the study statistical analysis of social phenomena and processes in the Murmansk region, as well as the method of predictive estimates of population dynamics was used. As a result of the research, trends in demographic development were identified, a forecast of population size was made taking into account changes in retirement age, and the situation on the labor market, living standards and pensions in the Murmansk region was analyzed. The study concluded with the following thesis: under the new pension reform, the low standard of living of pensioners is a social challenge, and their growing number will cause an expansion of social localization of poverty.
\end{abstract}

Keywords - Russian Arctic, Murmansk region, demographic situation, standard of living, retirement age.

\section{INTRODUCTION}

In 2018, Russia launched a new pension reform, the main goal of which was to raise the retirement age to meet the challenges of increasing pension payments and improving the living standards of elderly citizens in the future. The planned preferential changes to increase the retirement age for Russian Arctic residents were 60 years for men (the current threshold is 55 years) and 58 years for women (the current threshold is 50 years). From the point of view of timeliness for fundamental science [1, p. 588], there is a multivariate urgency of assessment of interrelations between the planned increase in the retirement age $[2$, p. 8$]$ and socio-economic development of the Russian Arctic [3, p. 187], because it is the regions of the Russian Arctic that are the driver of sustainable development and national security in Russia [4]. From the point of view of economic policy, the need to accelerate the growth of the national economy and productivity is the reason for the relevance of such an assessment [5, p. 34]. From the point of view of territorial management and marketing, the relevance of such an assessment is due to the sensitivity of the socio-economic situation in the Russian Arctic to changes in social transfers to the population, sustained demographic losses and declining labor quality [6, p. 714], and the formation of a new paradigm for the development of Russia's Arctic regions. From the point of view of social policy [7], this urgency is due to improvements in the quality of life of the population, primarily in the level of material well-being of elderly citizens.

Murmansk region is a strategic region of the Russian Arctic [8, p. 258] due to the following circumstances. The region is home to more than 60 largest mineral deposits; mining (half of which is located in Kirovsk and about one third in Kovdorsky Raion) and metallurgy account for more than half of industrial output [9]. The transport component positions the region as the transport gateway to the Russian Arctic: the Murmansk region, which is connected to the industrially developed Russian regions by rail, sea, air and road, is at the junction of transnational routes [10]. In the Murmansk region there is a base of Atomflot ships, the readiness of which is ensured by the repair plants located here. The key asset of the Murmansk region is human potential qualitative characteristics of a person, whose problems of life activity are especially clearly manifested in the Arctic conditions [11].

\section{MATERIALS AND Methods}

Our research was based on a comprehensive approach, which made it possible to analyze social challenges of the current stage of pension reform in Russia. The object of the study was the social sphere of the Murmansk region, namely 
the demographic situation, the situation in the sphere of labor and employment, as well as the living standards of the population. The Murmansk region was chosen because of the fact that the region is one of the typical old industrial regions of the Russian Arctic zone [12]. The Murmansk region is characterized by such systemic problems as obsolete production facilities and insufficient renewal of fixed assets [13, p. 266]. Mining specialization positions the region as dependent on the external situation of prices for the main export items, while the cost factors of northern regions impede economic diversification. Today, the Murmansk region is a strategic region of the Russian Arctic with a unique nature and distinctive culture, ensuring Russia's defense capability. The region's advantageous geopolitical position creates good conditions for sustainable socio-economic development. At the same time, the Murmansk region has a number of uncompetitive factors associated with difficult natural and climatic conditions, an insufficiently favorable environmental situation and a number of unresolved socio-economic problems. For over two decades, the region has experienced a high level of migration and natural decline, low life expectancy, deteriorating health, a shortage of qualified labor and other social problems [14] that have a negative impact on the region's socio-economic development and need to be addressed.

Many scientific papers have been devoted to Arctic social and economic development issues using the example of Murmansk region as an example, and a small part of them is related to the social component [e.g., 15-17]. The studies on social development of the regions of the Russian Arctic in the light of pension reform are unique, which updates our research

The methodological basis of our research was formed by the analysis and generalization of statistical indicators of the demographic sphere and living standards of the population (according to official statistics of the Federal State Statistics Service and its territorial body for the Murmansk region), methods of monographic survey (some aspects of the socioeconomic situation of the Murmansk region as a region of the Arctic zone of Russia) and economic and mathematical methods (with the help of which we made a long-term forecast of the number of people able to work in the Arctic region).

\section{DEMOGRAPHIC SITUATION IN THE MURMANSK REGION}

The demographic situation in the Murmansk region has its own specificity, which is formed under the influence of natural and climatic, economic factors and functional features of the settlement system. Thus, almost $90 \%$ of the population lives in cities, which are the sources of labor force for cityforming enterprises. In 2019, $21 \%$ of the Oblast's population lived in mono-profile settlements themselves, including 54,300 people in monocities with the most difficult social and economic situation (Kovdorsky Raion, Kirovsk, Revda) and 100,800 people in monocities with risks of deterioration of their social and economic situation (Monchegorsk, Olenegorsk, Zapolyarny, Nickel). [18, c. 120]. Population's estimates of the life situation in mono-profile cities and the self-sufficiency of territorial development, as well as status self-identification, are much lower than those of cities with diversified economies in the region [19, p. 1137]. On the other hand, in Murmansk Region there are significant differences in the values of standardized mortality rates, in male mortality rates in rural municipalities (Lovozero and Tersky municipal raions) and in closed administrative and territorial units of the region (ZATO Alexandrovsk, Zaozersk, Ostrovnoi, Severomorsk) [20, p. 205].

In 2002-2019, the population of Murmansk Oblast decreased by $16.7 \%$ (from 889,800 to 741,400 people). The number of men decreased by $17.7 \%$ and women by $15.7 \%$ over this period.

The changes in the age structure of the population are as follows: against the background of an increase in the share of population older than working age by $34.1 \%$, the share of population younger than working age in 2002-2019 decreased by $13.1 \%$, the share of population younger than working age decreased by $27.6 \%$. In 2018 , per 1,000 people of working age there were 320 people younger than working age, 386 people younger than working age. - Over the working age; the total demographic burden was 706 people. In 2019, the population of retirement age in the Murmansk region was 176.7 thousand people. The number of men aged 60 and over was 47,600 people, women (55 years and over) - 129,200 people. A positive trend in the demographic situation in Murmansk region is an increase in life expectancy: during the period under review, it increased by $9.5 \%$, including $6.6 \%$ for women and $10.5 \%$ for men. In 2018 the average age of population of the region was 38.8 years, including men - 35.7 years, women - 41.7 years; urban population - 39.1 years, rural population 35 years.

The natural loss of population in the Murmansk region in 2002-2019 was 20.7 thousand people, including men - 35.7 years, women - 41.7 years, urban population - 39.1 years, rural population - 35 years. (in 2012-2015 the region registered natural population growth); the value of birth rate was $9 \%$ against $9.8 \%$ in 2002 , mortality rate - $11.4 \%$ (13.2\%o). Natural population growth in the region is recorded in closed administrative-territorial formations and in the Badjanak region (such settlements have military and military-industrial specialization). In particular, in 2019 natural population growth was 5.3\% in the ZATO of Severomorsk, $6.3 \%$ in the ZATO of Alexandrovsk, and 8.3\%o in the ZATO of Vidyaevo settlement (for comparison, in Tersky Raion natural population decline was $14.5 \%$, and in monocities of Monchegorsk and Kirovsk - 5.7 and 4.9\%o, respectively). In 2019 , the population mortality rate was 1136.3 deaths per 100,000 people. The main types of mortality were circulatory diseases (592.7), neoplasms (203.2), external causes (112.3, including causes of death due to alcohol - 48.2, transport accidents - 9.4).

The migration loss of population in 2000-2019 was 122.5 thousand people. In the total migration flow $83.3 \%$ are migration ties with other regions of Russia. In 2019, $45.4 \%$ of the population in the migration decline was of working age, $43.7 \%$ - the population older than working age. In general, the migration outflow rate in the region in 2019 was $-6.5 \%$, including Murmansk - -13\%o, Olenegorsk - 12.3\%, Kandalaksha district $-11.1 \%$, Polyarnye Zori $-10.3 \%$. On the contrary, in Lovozero district the migration outflow coefficient was $11.2 \%$, in Kola district - 5.3\%o, in Monchegorsk city - 4.1\%o.

\section{EMPLOYABLE POPULATION IN THE MURMANSK REGION: FORECASTED ESTIMATES BASED ON CHANGES IN RETIREMENT AGE}

Using data from the official demographic forecast to 2036, data from Rosstat on the gender and age structure of the 
population of the Murmansk region, the scheme to increase the retirement age, we made a long-term forecast of the number of able-bodied population of the region, taking into account the increase in retirement age. Analysis of such a forecast [21, p.165] shows that in the Murmansk region since 2000 there is a significant decline in the number of ablebodied population. If the working age for women (16-50 years) and men (16-55 years) remains the same (for residents of the Russian Arctic before the pension reform), the number of able-bodied population is forecast to decline further by $0.73 \%$ per year on average. According to our calculations, by 2036 the decline will reach $14 \%$ compared to 2018. (only 389,000 people will remain able to work in the Murmansk Region). Under the new retirement scheme, the rate of decline of able-bodied population is projected to decrease to $0.14 \%$ per year on average. According to our estimates, by 2027 the population decline will practically stop and by 2036 , when the number of able-bodied population will decrease by $4.4 \%$ compared to 2018 and no more than 433 thousand people will remain able-bodied in the Murmansk region.

This differs from the situation in Russia as a whole. Thus, in our previous studies [22, p. 69] we made three options for forecasting the number of able-bodied population of Russia in 2018-2036, taking into account an increase in retirement age. According to our estimates, an increase in retirement age has changed the trend of declining population - the number of able-bodied population in Russia is expected to increase, including in all three variants of the forecast.

\section{LABOR MARKET OF THE MURMANSK REGION: TRENDS, TRENDS}

The following trends emerged in the labor market of the Murmansk region in 2002-2019. During the period under review, the region's labor force (table I) decreased by $20 \%$ (105,200 people). A negative trend is an increase in the number of people employed in the informal sector $(9 \%$ of the total workforce were employed in the informal sector in 2018), against a background of an $80.7 \%$ decline in the share of people employed in basic work in 2018) and an increase in the number of people employed in additional work (19.3\%).

TABLE I. LABOUR MARKET CHARACTERISTICS OF THE MURMANSK REGION, 2002, 2019 [23]

\begin{tabular}{|l|c|c|}
\hline \multicolumn{1}{|c|}{ Indicator } & $\mathbf{2 0 0 2}$ & $\mathbf{2 0 1 9}$ \\
\hline Labor force, thousand people. & 526.5 & 421.3 \\
\hline $\begin{array}{l}\text { Employed population aged 60-72 years, \% of } \\
\text { the total number of employed people }\end{array}$ & 3.6 & 6.9 \\
\hline Unemployment rate, \% & 10.3 & 5.4 \\
\hline $\begin{array}{l}\text { Unemployed population aged 60-72 years, \% } \\
\text { of the total number of the unemployed }\end{array}$ & 6.8 & 7.0 \\
\hline $\begin{array}{l}\text { Share of the unemployed looking for a job for } \\
12 \text { months or more, \% }\end{array}$ & 46.1 & 25.0 \\
\hline $\begin{array}{l}\text { Load of the unemployed population } \\
\text { registered with the employment services per } \\
\text { one declared vacancy }\end{array}$ & 5.7 & 0.6 \\
\hline
\end{tabular}

Positive trends in employment in the region include a significant reduction in unemployment by a factor of 1.9 (from $10.3 \%$ in 2002 to $5.4 \%$ in 2019) and in tension on the labor market. Thus, the proportion of unemployed who have been looking for work for more than 12 months has decreased by 1.8 times, and the load of unemployed population per one declared vacancy - by 9.5 times. The share of need for workers to fill vacant jobs in the total number of jobs in the regional labor market as of 31.10.2018. [24] was $2.5 \%$.

By types of economic activity, the largest share of demand for workers to fill vacant jobs was accounted for by "wholesale and retail trade" (6.7\%), "activity of hotels and catering enterprises" (6.5\%), "administrative activity and related additional services" (5.6\%), "information and communication activity" (5\%). By professional groups - for employees of service and trade, protection of citizens and property $(4.4 \%)$, employees engaged in the preparation and execution of documentation, accounting and maintenance $(4.3 \%)$, skilled workers in the industry, construction, transport and working related occupations $(3.6 \%)$.

By region's municipality [25], the highest unemployment rate in 2019 was recorded in Tersky Raion (9.9\%) and Lovozero Raion $(6.2 \%)$; traditionally low unemployment rates were recorded in ZATO Severomorsk $(0.6 \%)$ and Alexandrovsk $(0.9 \%)$, and in the regional center $(1 \%)$. Monocities with high registered unemployment rates include Revda (4.4\%) and Nickel (3.3\%), and Olenegorsk (1.7\%).

As for people older than working age on the labor market of Murmansk region, the share of the population aged 60-72 in the total number of employed people was $6.9 \%$ against $3.6 \%$ in 2002 ; in the total number of unemployed people it was $7 \%(6.8 \%)$. The share of working women pensioners is $30.2 \%$ of the total number of working women and $39.8 \%$ of the total number of working men pensioners [23]. According to sample labor market surveys in the region [23], of the total number of people of working age $1.3 \%$ have length of service for early retirement of less than one year, $75.1 \%$ - more than one year (including $52.3 \%$ of them who have length of service for early retirement of more than 15 years, $12.5 \%$ - 10-14 years, $9.6 \%$ - 5-9 years)

Under the regional project "Elder Generation" of the national project "Demography" [23] in 2019. 812 preretirement citizens attended training courses in educational organizations in Murmansk, St. Petersburg, Izhevsk, Voronezh, etc. Unemployed citizens were trained under the programs "Cook", "Archivarius", "Guardian", "1C: Enterprise 8 Trade Management", "Enterprise Accounting", "Category C and E Driver", etc. in 20112. Employees of preretirement age (735 people) were trained under the programs "Social Teacher", "Monteur of the Way", "System Administrator", "Little Nurse", "Specialist in the field of procurement", "Ensuring the reliability of electrical networks in the production of operational switching", etc. The share of persons of pre-retirement age, who remained employed and received professional training, was $100 \%$.

\section{STANDARD OF LIVING OF THE POPULATION OF THE MURMANSK REGION}

In 2002-2019, the share of the population in the Murmansk region with average per capita monetary incomes below the minimum subsistence level fell by half (from $22.6 \%$ in 2002 to $10.8 \%$ in 2019). Nevertheless, the growth in material welfare was insignificant: the ratio of average monthly wages to the minimum subsistence level of the working population was $34.8 \%$, the average per capita cash income to the minimum subsistence level was $22 \%$, and pensions with a pensioner's minimum subsistence level was $65 \%$. It should be noted that the values of such indicators were lower than the Russian average. 
Almost $67 \%$ of the population of Murmansk region (data for 2018 [25]) was in relative poverty (the average per capita income of this proportion of the population was not higher than the regional average); more than $47 \%$ of households in the region assessed their financial situation as below the socially acceptable level. In $2018,5.9 \%$ of the region's poor were older than working age.

The current level of purchasing power of pensions in Murmansk region limits the ability of pensioners to lead decent lives [26, p. 167]. At the same time, $68.1 \%$ of people older than working age (data for 2018 [24]) complain about problems related to living conditions: $39.1 \%$ of them - about the inaccessibility of medical services, $27.3 \%$ - about the poor organization of public transport, $14.5 \%$ - about the significant distance of places for recreation and leisure, $12.6 \%$ - about the significant distance of pharmacies, $8.4 \%$ - about the significant distance of shops.

\section{STANDARD OF LIVING FOR PENSIONERS OF THE MURMANSK REGION}

In the structure of total household income in the Murmansk region, $78.5 \%$ (2018, [24]) is income from work (53.7\% in pensioner households), and $20.9 \%$ (46.1\%) of transfers in cash and in kind. In the structure of social benefits - $30 \%(49.1 \%)$ of benefits and social payments to persons eligible for social support measures, $28.3 \%$ (49.3\%) - housing subsidies and monetary assistance to pay for housing and communal services.

In the structure of social payments to the population of Murmansk region, $77.8 \%$, while the Russian average was $73.9 \%$.

By municipality, the largest share of pensioners is in Tersky Raion (49.8\%), Kovdorsky Raion (42.8\%), the city of Kirovsk (41.9\%), Kandalaksha Raion (41.4\%) and the city of Apatity (40.4\%); the smallest share is in Pechenga Raion $(27.2 \%)$ and the city of Olenegorsk (30.4\%).

In the structure of pensioners of the Murmansk region, the largest share of pensioners receiving old-age pensions $(91.4 \%$, in $2002-86.2 \%$ ). The average size of the pension in the region in 2018 was 1.56 of the minimum subsistence pensioner $(0.81$ - in 2002), including old-age pensions - 1.62 (0.85), disability pensions - $1.00(0.58)$, survivor pensions - $0.84(0.41)$, social pensions - $1.00(0.58)$.

In the municipalities of the Murmansk region differentiation of living standards for pensioners (in terms of the ratio of pensions to the value of the minimum subsistence pensioner) - is insignificant: from 1.40 times in the Tersky district to 1.58 times in the city of Polar Zori. The average replacement rate of pensions in 2019 in the Murmansk region was $30.1 \%$ (in $2002-24.8 \%$; the highest value of this indicator was recorded in 2015. - - 36,1\%).

In 2019, the highest pension replacement ratio in the region was in Lovozero Raion $(40.4 \%$, while the average salary in the region was $75 \%$ of the Oblast average and the average pension was $97.2 \%$ ). The lowest value of the pension replacement ratio was recorded in cities and districts, where the average monthly wage and average pension are higher than the regional average (in Kirovsk - 27.2\%, $120.1 \%$ and $104.8 \%$, respectively, in Pechenga district $-28.6 \%, 110 \%$ and
$100.6 \%$, in the city of Polar Zori $-21.6 \%, 154.9 \%$ and $107.1 \%$, respectively).

\section{VIII.CONCLUSION}

The task of assessing the relationship between raising retirement age and socio-economic development of the Murmansk region is relevant. This is due to the special sensitivity of social and economic processes in the Murmansk region to changes in social guarantees for the population, sustainable demographic losses, as well as problems in staffing the regional economy.

World studies show that the increase in the retirement age is associated with internal demographic reserves, in particular, with an increase in life expectancy [27, p. 511]. This trend is characteristic of the Russian Federation: according to demographic forecasts, life expectancy is expected to increase further (according to forecast estimates [24], by 2035 life expectancy of the population of the Murmansk region will be 78.97 years, including 74.94 years for men and 82.69 years for women). In the context of the new pension reform, the low standard of living of pensioners is a social challenge, and their growth (from $23.8 \%$ in 2019 to $28.7 \%$ by 2035 in Murmansk Region) will cause an expansion of social localization of poverty.

Thus, the dynamics of the number of able-bodied population in Murmansk Region differs significantly from the all-Russia dynamics. An increase in the retirement age in Murmansk Region will not be able to ensure an increase in this indicator.

\section{ACKNOWLEDGMENT}

The reported study was funded by RFBR according to the research project № 19-01-00022 «The impact of the pension reform on the economic development of the regions of the Arctic zone of the Russian Federation».

\section{REFERENCES}

[1] S. Harper, "Economic and Social Implications of Aging Societies", Science, 2014, vol. 346 (6209), pp. 587-591. DOI: 10.1126 / science. 1254405 .

[2] J. Tyrowicz, K. Makarski, M. Bielecki, "Reforming retirement age in DB and DC pension systems in an aging OLG economy with heterogenous agents", IZA Journal of Labor Policy, 2016, vol. 5 (1), pp. 8. DOI:10.1186/s40173-016-0067-8.

[3] V. Danielyan, V. Polterovich, "The Adventures of Pension Reform in Russia: Where Are the Mistakes?", Journal of the New Economic Association, 2019, vol. 42 (2), pp. 186-194.

[4] L.V. Larchenko, A.V. Kolyshkin, T.V. Yakovleva, "The reproduction of the mineral resource base as the basis for the sustainable development of the resource-producing regions of the North and the Arctic", IOP Conf. Series: Materials Science and Engineering, 2020, vol. 753, pp. 062016. DOI:10.1088/1757-899X/753/6/062016.

[5] A. Kudrin, E. Gurvich, "A new growth model for the Russian economy”, Russian Journal of Economics, 2015, vol. 1, issue 1, pp. 3054.

[6] E. A. Korchak, "Sustainable development of the Russian Arctic: the role of labor potential", Proceeding of the International Science and Technology Conference "FarEastCon 2019", 2020, vol. 172, pp. 713724. DOI: 10.1007/978-981-15-2244-4_67.

[7] M. E. Biresselioglu, M. H. Demir, B. Solak, A. Kayacan and S. Altinci "Investigating the trends in arctic research: The increasing role of social sciences and humanities", Science of The Total Environment, 2020, vol. 729, pp. 139027. DOI: 10.1016/j.scitotenv.2020.139027.

[8] A. Eglington, R. Israel and R. Vartanov, "Towards sustainable development for the Murmansk region", Ocean \& Coastal 
Management, 1998, vol. 41, issues 2-3, pp. 257-271. DOI :10.1016/S0964-5691(98)00068-4.

[9] D. Gritsenko, E. Efimova, "Is there Arctic resource curse? Evidence from the Russian Arctic regions", Resources Policy, 2020, vol. 65, pp. 101547.

[10] A. A. Biev, N. A. Serova, "Features of the organization of fuel supplies to the Arctic regions of Russia: assessment of transport conditions", IOP Conference Series: Earth and Environmental Science, 2020, vol. 539, pp. 012017. DOI: 10.1088/1755-1315/539/1/012017.

[11] Y. Bolsunovskaya, A. Sentsov, "Human potential as a strategic resource of the Russian Arctic sustainable development", Web of Conferences, 2016, vol. 28, pp. 01013. DOI: 10.1051/SHS 28 shsconf/20162801013.

[12] A. Kozlov, S. Gutman, E. Tereshko, "Industry and Entrepreneurship component of the Murmansk region construction complex strategic chart", E3S Web of Conferences, 2019, vol. 91, pp. 05011. DOI: 10.1051/e3sconf/2019910.

[13] T. Skufina, S. Baranov, V. Samarina, T. Shatalova, "Production functions in identifying the specifics of producing gross regional product of Russian Federation", Mediterranean Journal of Social Sciences, 2015, vol. 6, no 5, pp. 265-270. DOI: 10.5901/mjss.2015.v6n5s3p265.

[14] E.A. Korchak, "Long-term dynamics of the social space in the Russian Arctic", IOP Conference Series: Earth and Environmental Science, 2020, no 539 (1), pp. 012006. DOI: 10.1088/1755-1315/539/1/012006.

[15] O. N. Popova, I. V. Vicentiy, "Migration situation in the Russian Arctic (on the example of the Murmansk region)", IOP Conf. Series: Earth and Environmental Science, 2016, vol. 302, pp. 012086. DOI:10.1088/1755-1315/302/1/012086.

[16] M. Ivanova, O. Ostrovskaya, "Current trends of arctic workforce formation", Journal Of Advanced Research In Law And Economics, 2017, no. 4, vol. 8, pp. 1136-1150.

[17] T. P. Skufina, V. P. Samarina, H. Krachunov, D. Yu. Savon, "Problems of Russia's Arctic Development in the Context of Optimization of the Mineral Raw Materials Complex Use”, Eurasian Mining, 2015, no 2, pp.18-21. DOI: 10.17580/em.2015.02.05.

[18] E. V.Nedoseka, G.V. Zhigunova, "Features of local identity of singleindustry town residents (the case of the Murmansk Oblast)", Arctic and North, 2019, no 37, pp. 118-133. DOI: 10.17238/issn22212698.2019.37.118.

[19] E. Korchak, N. Serova, "High-quality reproduction of labor potential of Arctic territories: migration factor", The European Proceedings of Social \& Behavioural Sciences EpSBS, 2019, vol. LXXVI, pp. 17361742. DOI: 10.15405/epsbs.2019.12.04.235.

[20] B.A. Revich, T. L. Kharkova, E.A. Kvasha et al., "Sociodemographic limitations of the sustainable development of Murmansk oblast", Studies on Russian Economic Development, 2014, vol. 25, no 2, pp. 201-206. DOI: 10.1134/S1075700714020087.

[21] S. V. Baranov, T. P. Skuf'ina, I. A. Gushchina, "The Impact of the Retirement Age Increase on the Economy and Attitudes of the Population of the Murmansk Oblast”, Economic and Social Changes: Facts, Trends, Forecast, 2020, vol. 13, no 1, pp. 160-173. DOI: 10.15838/esc.2020.1.67.9.

[22] T. Skufina, S. Baranov, V. Samarina, E. Korchak, "Increasing GDP production in the Russian Federation and raising the retirement age: is there a connection?", AD ALTA: Journal of Interdisciplinary Research, 2019, vol. 9, issue 1, special issue VI, pp. 69-72.

[23] Federal State Statistics Service. URL: https://rosstat.gov.ru/. (accessed 10.11.2020).

[24] Territorial department of the Federal State Statistics Service for the Murmansk Region. URL: https://murmanskstat.gks.ru/. (accessed 09.12.2020).

[25] Interactive portal of the employment service of the population of the Murmansk region. URL: https://murman-zan.ru/. (accessed 15.11.2020).

[26] A. E. Ilyin and D. V. Dolzhenkov, "Consumer capacity of pensions in the region", Bulletin of the Kursk State Agricultural Academy, 2018, no 5, pp. 166-169.

[27] A. Puur, L. Leppik and M. Klesment, "Changes in Pension Take-up and Retirement in the Context of Increasing the Pension Age: The Case of Estonia in the 2000s", Post-Communist Economies, 2015, vol. 27, no 4, pp. 497-516. 